\title{
自然光の構成とその知覚状態からみた 建築空間におけるまとまりと方向性を与える自然光夕イプ THE PROTOTYPES OF NATURAL LIGHT WHICH GENERATES UNITY OR DIRECTION TO AN ARCHITECTURAL SPACE
}

\author{
小泉＼cjkstart隆*，桶師徳 行**，鈴木信 宏*** \\ Takashi KOIZUMI, Tokuyuki OKESHI and Nobuhiro SUZUKI
}

\begin{abstract}
There is natural light which generates unity or direction to an architectural space. We obtained the prototypes of such light by examining the location and form of the light in the space and perception of the light and the space. We have classified unity into 3 types: central light, enclosing light, saturating light and direction into 2 types: axial light and focal light on the axis of the space. The spatial effects of the light are essential and we named them as the characteristics of each type. Saturating light is unique in the natural light which can not be seen in objects' order.
\end{abstract}
keywords: prototypes of natural light, unity and direction of the space, location and form of the light, perception of the light and the space, spatial effects of the light, a prototype and variations 自然光タイプ，まとまりと方向性，自然光の構成（位置と形態）， 光と空間の知覚状態，自然光の空間的役割，原理タイプとヴァリエーション

1.はじめに

自然光を建築内部空間にどう導き入れるかは、その空 間の特性を决定する上で重要である。

空間特性に関わる自然光の中で、自然光が主要な要素 となって空間全体にまとまりや方向性を与えるものがあ る。まとまりは空間を体験する主体にその空間をより一 つの形ある実体として認識させるものであり、方向性は 空間における主体の運動衝動 ${ }^{12}$ として、共に空間の基本 的特性である。

例えば、パンテオンでは空間中央上部のドーム頂部に あり、空間内で際立って知賞できる天空の光が集中点と なって空間にまとまりを与えている。また通路上の空間 においてその通路の端部にあり、その空間形態によって 限定・方向づけられた視線の先端で明るく際立つ光が目 標となり、そこへと集中するように空間の方向性を強め ている場合などである。そこでは空間内で際立って知覚 できる自然光が中心や目標といった空間の構造要素と
なってまとまりや方向性をつくりだすとともに、それ が自然光であって常に動くが故に空間を豊かに生 きづかせている

そのような自然光にも多様なヴァリエーションがあり そうだが、それらは空間に対する自然光の構成とそれら 光と空間の知賞状態によって幾つかのタイプに整理でき そうである。本研究ではそのような自然光タイプを整理 し、採光設計に役立てたいと考えた。

\section{2. 研究の目的および視点}

自然光が主要素となって空間全体にまとまりや方向性 を与えている多数実例を対象に、そこでのま之まりや右 向性を与える自然光タイプを 1) 空間に対する自然光の 構成およびそれら 2) 当と染間の知賞状熊に求め整理す る。又まとまりと方向性の 3) 特性生成に扰忆る光のて 間的役割を各タイプの特徴として求め整理する。

物が主要素となってまとまりや方向性を与えている空
* 東京理科大学工学部建築学科 助手·工修

** 富永譲フォルムシステム 工修

*** 東京理科大学工学部建築学科 教授.工博
Research Assistant, Dept. of Architecture, Faculty of Eng., Science Univ. of Tokyo, M. Eng.

Yuzuru Tominaga + Form System Institute, M. Eng.

Professor, Dept. of Architecture, Faculty of Eng.,

Science Univ. of Tokyo, Dr. Eng. 
間を対象に、そこでのまとまりや方向性の特性およびそ の要因について論じたものは良くみられるが2)、本研究 は空間内で際立つ自然光が主要素となって空間のまとま りや方向性を作りだしている建築内部空間を対象に、建 築の一要素としての自然光操作という視点からそこでの ま之まりと方向性について捉え直し、自然光設計のデザ インガイドラインとして役立てようとした。

そしてまとまりと方向性を与えるその自然光タイプを 多様なヴァリエーションを包括できるようなレベルにお いて、空間中央に点的にある光といった、空間に対する 光の位置と形態による1) 空間に対する自然光の構成 と、空間内での主要な視野において、その際立った光と 広がりをもった周囲空間を同時に知賞、視野の上限を越 えるように光を知覚といった、まとまりと方向性の生成 を容易に知賞・認識させる為の 2)光之空間の知賞状 蛅に求め整理する。そして光が集中点となって空間をま とめる、望間の軸線を可視化するといった、まとまりと 万向性の 3 ) 特性生成に求ける光の空間的役割を各自 然光タイプの特徴として整理する。

既報「徳利屋いろりの間の空間構造と光」1「ウィー

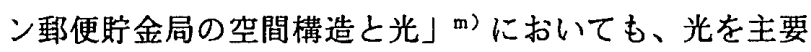
因とする空間構造に関わるイメージとしてのまとまりと 方向性があった。本研究ではそれらの例に加え、その他 多数実例に対象範囲を広代、ま之まりと方向性を与える 自然光夕イプを整理することが、一実例におけるイメー ジと要因の関係を越えて一般性のあるテザインガイドラ インが得られると考えた。

\section{3. 赫鼬察例}

既往理論で言及されているまとまりと方向性の要因に 注意しながら、空間に対する自然光の構成及びそれら光 と空間の知覚状態が要因となってまとまりや方向性を与 えていると判断した実例三百数例でを対象実例とした。

\section{4. 研究访洗}

対象実例に対する作者及び第三者の記述を補助的資料 にしながら、研究者の対象実例の研究視点に基づく観察 (写真上図面 ${ }^{8)}$ 、重要実例については加えて実地調㚗 9)）より、ま之まりと方向性をあたえる自然光タイプお 上び特性生成における光の空間的役割を整理した ${ }^{10)}$ 。

そしてその結果が一般性のあることを、既往理論を適

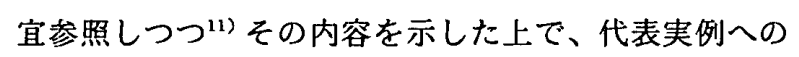
結果あてはめの解説によって示した。

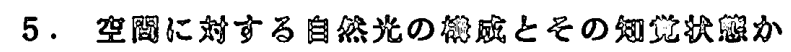

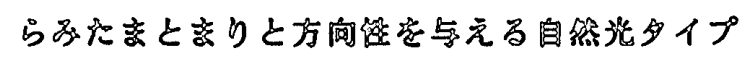

対象実例の研究の視点に基づく観察から、まとまりや 方向性を与える自然光タイプを検討したところ、まとま
り之方向性の相互に関わる自然光や原理的に関連しあっ ているもの、また具体的なヴァリエーションのレベルに おいて複数のタイプの複合、或いは夕イプの中間として 位置付けられるものなどがあった。本研究ではそれらに 対し相互の関連を包括する上位概念でタイプを整理せ ず、主要な原理に着目して具体的な設計手法として用い やすいレベルでタイプを整理することにした．そして他 タイプとの関連については適宜補足することにした。

そのような考え方に基つきき自然光タイプを整理した結 果、まとまりについて、1.1 中心光、1.2 包囲光、1.3 充満光、方向性について、2.1 軸線光、2.2 軸上目標光

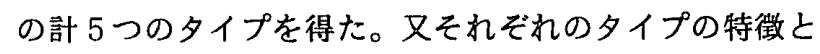
して特性生成に拈ける光の空間的役割を得た（表 1 ）。 以下各自然光タイプ毎に、その内容および代表例を解説 する ${ }^{12)}$ 。

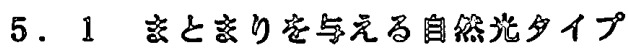

\section{(1) 吣心光}

空間の中心を強調することによって、空間のまとまり は強まると考えられる ${ }^{13)}$ 。

この中心光タイプは、杂間形態中央近傍（位置）に点 的 (形態) にある際立ち光が、集中点として空間の中心 となりその周囲の空間をまとめるものである ${ }^{15)}{ }^{16)}$ 。

光之空間の知賞状態は、視野中央の光と広がりをつ 周囲空間を同時知覚する、に整理できた。

ヴァリエーションは、光位置の空間形態中央近傍をさ らに1）平面中央一致と2）平面中央偏心に整理した。 また空間全体に対し点的な光 (形態)をその光の具体形 状より点状の光が空間全体に対し点的にある 1）点状点 的光、面状の光が点的にある 2) 面状点的光、線状の光 が点的にある 3）線状点的光 ${ }^{17)}$ に整理した。

ここでは代表例として、平面中央一致する位置に点状 点的光をもつパンテオンと平面中央偏心した位置に、鉛 直線状点的光をむつ M I T チャペルを解説する。

1) パンテカン（写真 1 、図 1)

EX1: Pantheon/Rome, Italy/120-124

$\angle$ Emperor Hadrian

空間に対する自然光の構成：直径 $43.2 \mathrm{M}$ の球を内接す るように上部がドームで下部半分がシリンダー状の空間 全体形である。そして平面中央の真上、ドーム頂部に開 口部素材のはいっていない直径約9Mの円形の天䢿を もっている。その直径約9Mの天空は、空間全体の直㹩 43.2Mにたいして、直径比 $9: 43.2 \doteqdot 1: 4.8$ 之、空間全体 形に対して小さく点的にある点状の光である。

光と空間の知覚状態：周囲が厚い壁に閉じられ闍が支 配的な空間のなか、天空の光は空間内の蛢燭や照明の明 かりに比へて自然光であるがゆえに格段に輝度が高い。 その為その光は周囲に対して輝度対比によってひときわ 
表 1 まとまりと方向性を与える自然光タイプとその代表例 :

空間に対する自然光の構成と光と空間の知覚状態及び特性生成における光の空間的役割

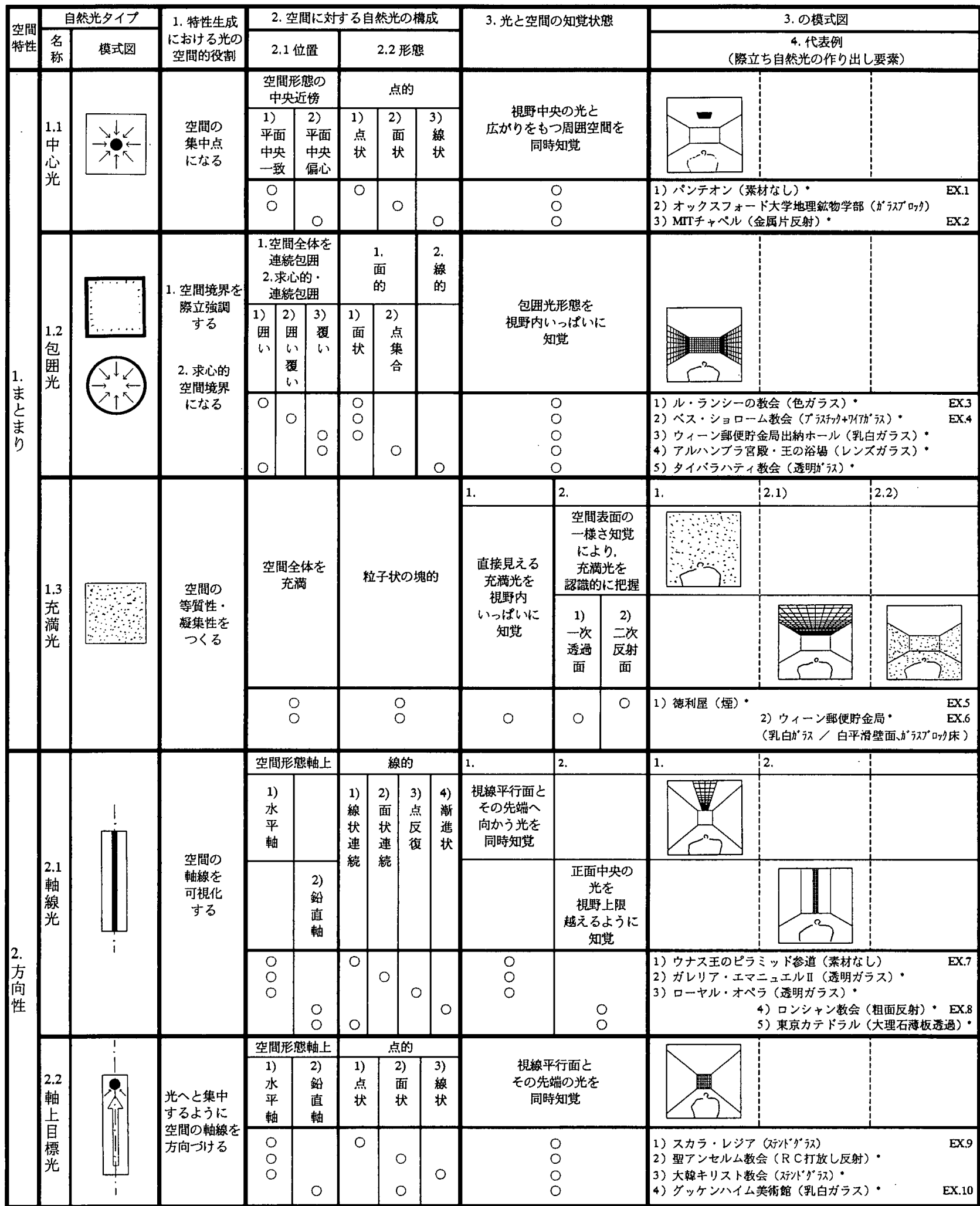

自然光タイプ模式图の凡例

自然光

空間形態
3.の模式図の凡例

自然光
4.代表例の凡例

* : 実地調查を行なった実例

$\mathrm{EX}:$ 本稿で取り上げた実例 
際立って明るく輝く。その天空は開口部素材がはいってい ないが、ホール床からの知覚距離が約 $40 \mathrm{M}$ 之遠いため、明 るく輝く点的な空のように見える。そのドーム頂部の際 立った光は、空間の天井が高く空間上部半分から上のドー ムのそのせり上がりに訜導される事も手伝って、自由に動 けるホールの至るところから容易に知賞され易い状態にあ る。その光を見上げたときの主な視野におけるその光と空 間の知覚状態を検討してみる。入口から礼择堂に入ったと ころ (A 点) で静視野 60 度で検討してみると、天空への視 角は約10度と小さく、その周团にドーム全体の約 8 割にわ たる周囲空間の広がりが同時に知覚できる。また天空真下 から見上げた場合（B点）は、天空への視覚は12度、その 周囲にドーム全体の約 6 割が同時に知賞できる。このよう にホールのいたるところからこの際だった天空の光をその 周囲筀間の広がりと同時に知覚できる。

R.アルンハイムは、パンテオンの天空について次のよ うに記述している。「建筑においても、中心という位置の 安定动果は、中略 例えばパンテオンの円蓋の円状の開 口部が果たしている。この円空は、そこに収束もしくはそ こから拡散する放射状の構造が、そこに接合している中央 の頂点を形成している」 ${ }^{18)}$ 。

2) MITチャペル（写真 2、図 2)

EX2: M.I.T. Chapel / Cambridge, Massachusetts, USA /

$1955 /$ Eero Saarinen

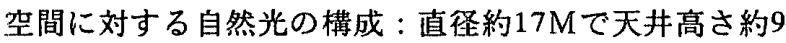
〜 7.5 M と祭壇に向かって下がり天井をもつシリンダー状 の空間全体形である。平面上の円形中央から約 $6 \mathrm{M}$ 後退し た正面軸上の祭壇上部には直径約4Mの円形のトップライ トがあり、そこからワイヤーで吊られた金色の金属片が トップライトから落ちる光によって、闓の中で 1 本の鉛直 な光の束として輝いている。この光は、祭壇天端（F L+

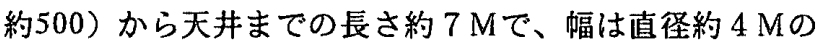
円弧の約 $1 / 4$ の約 $3 \mathrm{M}$ の鉛直線状の光であり、空間全体 の直径 $17 \mathrm{M} に$ 対して小さく点的にある光である。

光と空間の知覚状態：この金属片に反射した光も周囲か コンクリートと搷瓦の壁によって厚く閉ざされており閭が 支配的な架間のなかで輝度対比によって視覚的に際立って
いる。またこのトップライトからの光は、長さ約 1.5 Mの筒によって方向づけられ、そしてハニカム状のア ルミのスクリーンで拡散する為、外部の天候や光の入 射角が变わっても、常に安定して金属片に光が落ちる ように工夫がされている。また金属片自身もその上部 からの光を受け易くまた正面からその反射面が見え易 いよう少し前面に片むけられ吊られている。その金属 片の密度は上から下に政から密へと変化がつけられて いる。

その光は入口からの正面に位置し、杂間内で容易に 知賞しやすい位置にある。また空間全体形がシリン ダー形をしているため、ホール内部の広範囲からその 光が眺められる。いくつかの主要な視点場からその光 を眺めたときの光と杂間の知覚状態を検討してみる。 入口を入って 2 階バルコニーの下（A 点）、水平に静 視野60度で平面的にみた場合、幅約 $3 \mathrm{M}$ の光の束への 視角は約14度と小さく、その光を中央に㕵間全体を規 定しているシリンダー状の壁面の全周長のほほ $1 / 4$ にあたる約 $16 \mathrm{~m}$ が広がりをもって同時に知覚できる。 また断面的には祭壇天端から天井までにわたる長さ約 $7 \mathrm{M}$ の光の束の全体が視野内に収まる。また端の $\mathrm{B}$ 点 から検討してみても、同様に光を視野中央に、広がり をもった周囲空間を同時に知覚できる。

設計者であるエーロ・サーリネンは、MIT千ャペル について次のように述へている。「中心的な光は祭壇 から降り注ぐ。H.ベルトイヤー氏の金属小片からなる 彫刻スクリーンが、この光を無数の光のかけらにして 撒き散らす」 ${ }^{19)}$ 。この記述からこの祭壇上の光を空間 内での中心としてとらえ、際立たせようとしていた設 計意図が読み取れる。またD.K.チンは、MITチャペル の光の束のような鉛直の直線的な要素か、ある決った 望間のヴォリュームの中央に位置すると「自らが空間 の中心であることを主張し、自分と周りの壁面との間 に均質な罕間の領域を定める」とし、そして「その中 心がずれると、その柱によって、大きさやかたち、そ して位置の違いによって序列のついた、いくつかの空 間の領域が定まってくるだろう」と言及している20)。

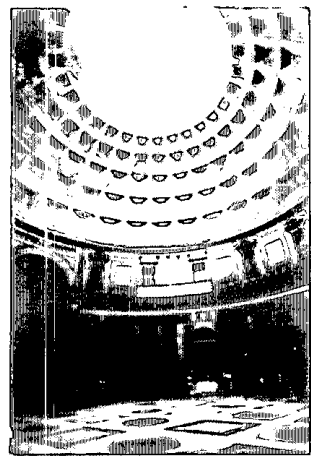

写碞1 パンテオン

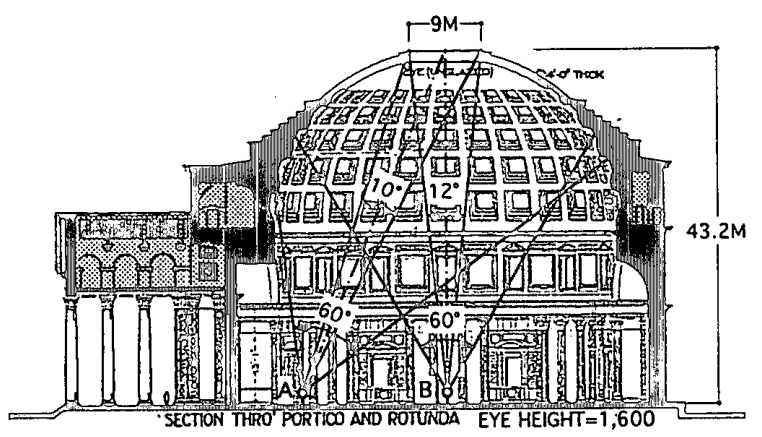

国 1 パンテオン 断面図

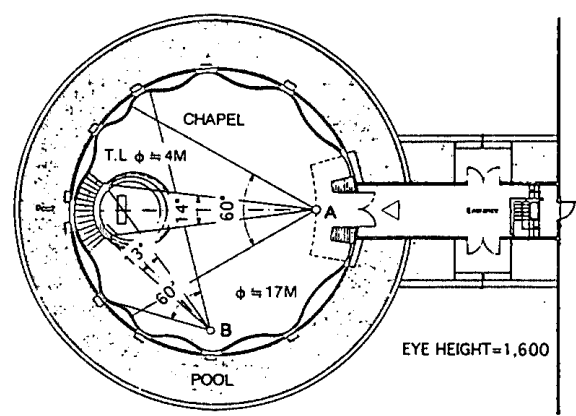

国2 M.I.T.チャペル 平面図 
MITチャペルでは、円柱のような光が中心となりなが ら、その平面中央から編心した光の位置により正面軸性 をもあわせもつ案間になっている。

\section{（2）包囲光}

内部空間の広がりを限定する空間の境界を強調するこ とによって空間のまとまりは強まると考えられる ${ }^{13) 。}$

この包囲光タイプは、空間全体を連続的に包囲する （位置）、面的あるいは線的な光 (形態) が、空間全体 の物理的境界として際だち、視知覚的に強調されること によって、空間にまとまりを与えるものである ${ }^{21) 。 ~}$ 又その包囲形態が求心的な場合は、境界の視知覚的強調 に加えて、その形態の求心性がまとまりを与える222。

光と空間の知覚状態は、包囲している光形態を視野内 いっぱいに知覚する、に整理できた。

ヴァリエーションは、光の位置の包囲については、

1）囲い、2）覆い囲い一体、3）覆いに整理した。光の 形態は、1.面的な光と、線的で環状に包囲する2.線的 光があったが、1.面的光はその具体形状よりさらに1) 面状面的光、2）点集合面的光に整理した。

ここでは、囲う面状面的光をもつル・ランシーの教会 と求心的に覆い囲む面状面的光をもつベス・ショロー ム・ユダヤ教会を代表例として解説する。

\section{1）ル・ランシーの数会（写真 3 )}

EX3: Notre-Dame du Raincy / Le Raincy, France /1923

\section{$/$ Auguste Perret}

空間に対する自然光の構成：幅約 $19 \mathrm{M} \times$ 奥行き約 $55 \mathrm{M}$ $\times$ 天井高約 $11 \mathrm{M}$ のほぼ直方体の空間全体形である。そし て空間の四周を囲むプレキャストコンクリートの非耐力 壁は、腰壁部分から天井一杯までを（高さ約 $10 \mathrm{M}$ ) クレ ストラと呼ばれる $60 \mathrm{c} \mathrm{m}$ 角を基本単位とする色ガラスが はめられた角格子によって構成されている。そのため空 間は色ガラスによる光の皮膜面によって連続的に取り囲 まれる。構造体である32本の独立柱は、直径 $43 \sim 35 \mathrm{~cm}$ と細く、また壁面から数 $\mathrm{cm}$ 離されていることが、より 一層光の皮膜面として見えることを強調している。光の 被膜面の色は、入口から祭壇に向かうにつれて全体的に

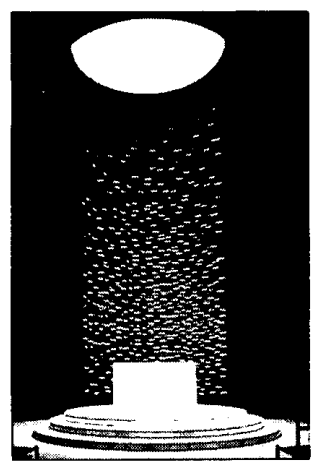

写真 2 M.I.T.チャペル

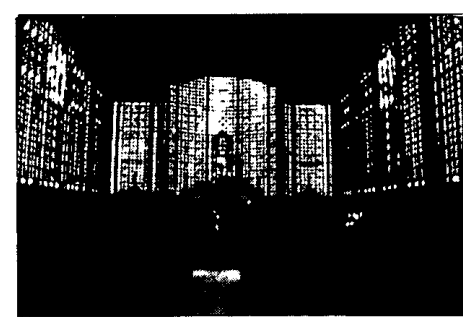

写真 3 ル・ランシーの教会
暖色から寒色へと変化している。

光と空間の知覚状態 : その光は薄暗い空間内 ${ }^{23)}$ で輝 度対比により際立っている。正面軸上祭壇方向に向かっ て静視野 60 度で光と空間の知覚状態を検討したところ、 入口部分から祭壇の手前（正面壁から約 $18 \mathrm{M}$ ) の所まで の間で、水平方向静視野60度の視野内に正面の幅約 $19 \mathrm{M}$ の光とその両側壁の光面が視野内いっぱいに同時に収ま る。また断面的には、腰壁から天井までにわたる約 $10 \mathrm{M}$ の全体が視野内に収まり、3面の光に囲われている構成 が容易に知覚できる。そして周囲に視線を移しても常に 光に囲われている構成が容易に知覚できる。

2) ベス・ショローム・ユダヤ教会（図 3)

EX4: Beth Sholom Synagogue/Elkins Park,

Pennsylvania, USA $/ 1959 /$ F.L.Wright

空間に対する自然光の構成：幅約 $34 \mathrm{M}$ の 6 角形の求心 形の平面に 3 本の大梁が斜めに㲘けられ、高さ約 $24 \mathrm{M}$ の 山形の断面形をしている。床面は祭壇へとむかって下 がっており、全体として山形の求心形の空間全体形であ る。そしてその 3本の大梁にかかるように、外側がワイ ヤガラスで内側がプラスチック（空陌 $2.5 \mathrm{c} \mathrm{m}$ ) の光面 が、空間を一体的に覆い囲んでいる。

光之空間の知覚状態 : その空間内で輝く光面 ${ }^{24)}$ は、 視野内いっぱいに大きな面積を持って知覚でき、空間を 一体的に覆い㬰んでいる構成が容易に知覚できる。

香山壽夫氏は、この教会の特徴として、視覚的ゲシュ タルトとして強いまとまりを持ち、「建物全体形が閉じ た山形をしていること」と、内部は半透明な皮膜を通し て射し込む光で満たされ「建築空間が光の量塊として扱 われていること」を挙げている25)。

\section{(3) 充淽光}

拡散透過性のある同一素材で㞬間全体を覆った場合な どにおいて、拡散した等質な光で空間が満たされる場合 がある。

充満光タイプは、このような空間全体に充満する（位 置)、粒子状の塊的 (形態) な光か、、架間の領域自体に 等質性・凝集性をつくりだし、空間のまとまりを強調す

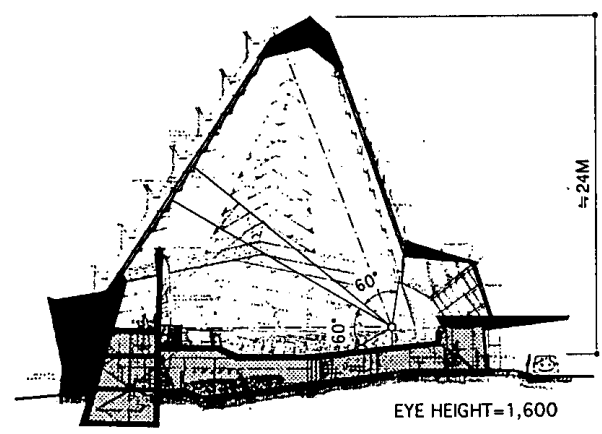

因3
ベス・ショローム・ユダヤ教会 断面図 
るものである。

境界によって限定された領域において、その領域を等 質なもので充満するとき、それがないときよりも領域の まとまりは強くなると考えられる26)（図 4)。

光之空間の知覚状態は、1. 煙などの微粒子に光が反射 し直接見える充満光を視野内いっぱいに知覚するタイプ と 2. 染間を充満する光は直接見えないが、空間表面の 輝度、色調等の一様さを知覚することによって、光が空 間に充渾している状的を認識的に把握するタイプ音にに 整理できた。そして後者はさらに1）充満する光を空間 に入射させる一次透過面の知賞によるもの之、2）充満 する光の受手となる二次反射面の知覚によるものの二つ に整理した。また本研究の視点を超えるか、空間内部に 充満する光により、温かさなどを体感的に感じとること が充荋光を認識的に把握するのに大きな要因であること が実地体験より確認できた。

代表例は知覚状態の異なる、煙によって見える光を視 野内いっぱいに知覚する徳利屋と、一次透過面や二次反 射面の一様さ知覚により認識的に充満光を把握する ウィーン郵便眝金局出納ホールを既報の結果 ${ }^{28)}$ に基づ き解説する。

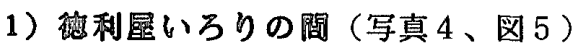

EX5: Tokuriya/Kiso, Japan $/ 1840$

正午過ぎの短い時間，天空からの直射光が煙の粒子に 反射して明るく青白い光に満ちた光の束となり、そこに 座す人を包み込んでいるとき，「人々を包み込む光に満 ちあふれた空間」とイメージされていた（図 5) ${ }^{29) 。 ~}$ またこの光の束は，晴天時その周田から知覚するとき に，光の束というある形をもったものとして并別され捉 えられている。これらより，煙のような微細反射物に よって直接知覚できる光に満ちた領域が、まとまりをも つことがわかる。

2) ウィーン郅健眝金局出的ホール（写真 5 、図 6) EX6: Postal Savings Bank's Banking Hall/Viena, Austria /1906/Otto Wagner

ウィーン郵便眝金局出納ホールでは、完全拡散に近い 光をつくりだす半透明な一様なガラス面が空間全体を包
み込むように湾曲面として連続していることが主要因と なって「一様な光で満たされた空間」という空間構造イ メージが捉えられた ${ }^{30)}$ 。そしてその「空間を包み込む 一様な光の膜」と一様な应散光が空間に満ちる効果がか さなって「光の塊で満たされた空間」 ${ }^{31)}$ という空間構 造イメージが捉えられた。

これらより実際は直接知賞出来ないか、その光を空間 に入射させる空間全体を包む大面積の一次光源の表面の 一様さを知賞することによって、空間を充満する光を認 識的に把握し、「光の塊で満たされた空間」といった空 間のまとまりに関する発展的なイメージを与えていたと 推察できる。

また物々に降り注ぐ白く委らかい一様な拡散光が「一 様な光で統一された物々の渠間」 ${ }^{322}$ というイメージを 与えていた。このように、一様な光が降り注き、同じ色 調や輝度をもつ反射面の知賞も充満する光を認識させる のに効果があると思われる。

四周が 6 層の建物で囲まれた深い井戸のような位置に ある空間であるが、実測吕) したところによるとホール 内の照度は，平均約 $1.3501 x$ で、暗くなっている北西角 を除くと、均整度は約 $1 / 2$ であった（図6）。

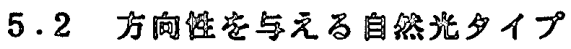

\section{(1) 蜼喼光}

空間形態がそのプロポーションによって方向性をもつ 場合、その空間形態軸上の（位置）、空間全体を貫く線 的な光 (形態) か、空間の軸線を可視化し、空間の方向 性を高めるタイプである ${ }^{34)}$ 。

ヴァリエーションは、光位置の空間形態軸上について は、1）水平軸之2）鈶直軸に整理し、光形態の線的な 光は、その具体形状により、1）線状連続線的光、2) 面状連続線的光、3）点反復線的光、4）漸進状線的光に 整理した。点反復線的光は、連続感をもって線状に光が 繰り返し配置されリズム感を伴った方向性を示すものと して、漸進状線的光は、粗い素材などに光が反射してそ の光の段階的に衰退する様が知覚できるものであり、方 向線を指し示すのみでなく、そこに方向付けをあたえる

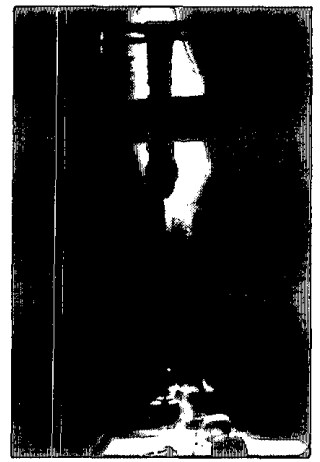

写愐 4 徳利屋 (正午) (撮影 : 鈴木研究室)

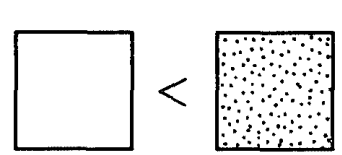

图 4 点充満による 領域内のまとまり度

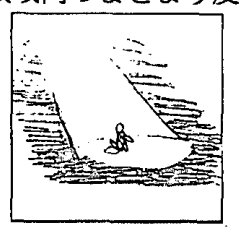

圈 5 徳利屋（正午） 被験者のスケッチ

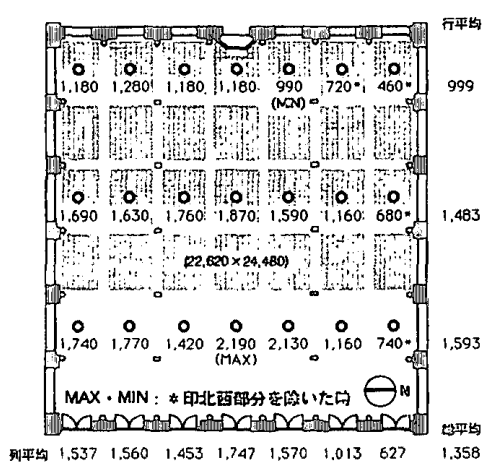

圈 6

ウィーン郵便眝金局出納ホール 平面図と照度分布 (単位 : $1 \mathrm{x}$ )

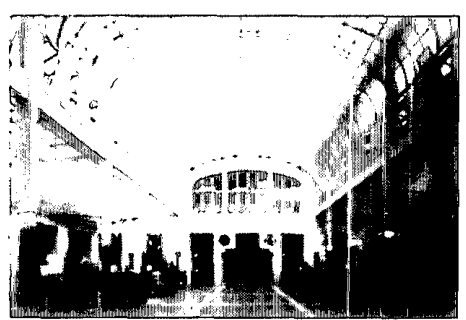

写槚 5 ウィーン郵便眝金局

(撮影：鈴木研究室) 
ものとして整理した ${ }^{35)} 。$

光と空間の知覚状態はその軸方向により異なり、水平 軸の場合は、視野内の大部分を占める視線に平行な面と 手前からその先端へ之向かう光を同時知覚する、鉛直軸 の場合は正面中央の光をその線的光の一端が視野の上限 を越えるように知覚する、に整理できた。

ここでは代表例として、水平軸上に線状連続線的光を もつウナス王のピラミッド参道と鉊直軸上に漸進状線的 光をもつロンシャン教会の小聖堂を解説する。

1) ウナス王のピラミッド参道（写真 6 )

EX7: Processional Way leading to the Pyramid of UNAS

/ Saqqara, Egypt/2356-2323 BC

空間に対する自然光の構成：一直線に数百メートルも 続く壁と天井に囲まれたトンネル状の長い通廊であり、 空間形態自身が強い方向性をもつ。そしてその空間形態 の対象軸上の天井に、幅数十 $\mathrm{c} \mathrm{m}$ のわずかな間隙だけを 残して開けられた天空の一条の溝がスリット状に細く長 く走っている。

光之空間の知覚状態：そのスリットの光は、周囲の大 部分が閉じられてるが故に暗い空間の中で、視覚的に際 だっている。そして強い方向性を持った空間形熊のた わ、空間内での主要な視線方向は通路方向に限定され る。その通路方向を見た場合、視野内の大部分を占める 視線に平行な面之手前からその先端へと向かう光を同時 知覚できる。

2) ロンシャン教会の小聖堂（図 7)

EX8: Chapelle Notre Dame du Haut Ronchamp/

Ronchamp, France / 1955/Le Corbusier

空間に対する自然光の構成：构子状の光の塔から入射 し、粗い石灰吹き付けの壁面を伝う光である。この筒状 の空間は、幅：高さ $=5.5 \mathrm{M}: 22 \mathrm{M}=1: 4$ と灴間形態自身 が鉊直方向の方向性を持っている。そしてその縦長の筒 状の空間形態のもつ鈶直軸と一致するように、粗い壁面 を上から下へと伝い反射する光が知覚できる。

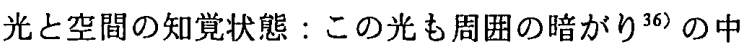
で、一際輝いている。そして小聖堂の前、もう一つの小 聖堂の間に壁面から16.5 M程度のひきがあり、そこはこ

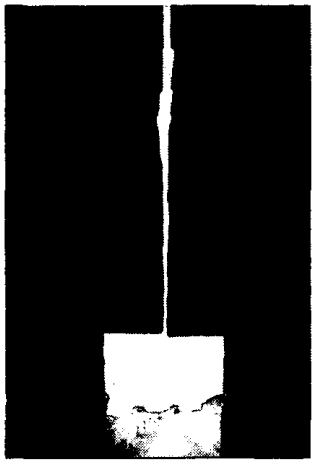

写真 6 ピラミッド参道 （撮影：関 和明氏）

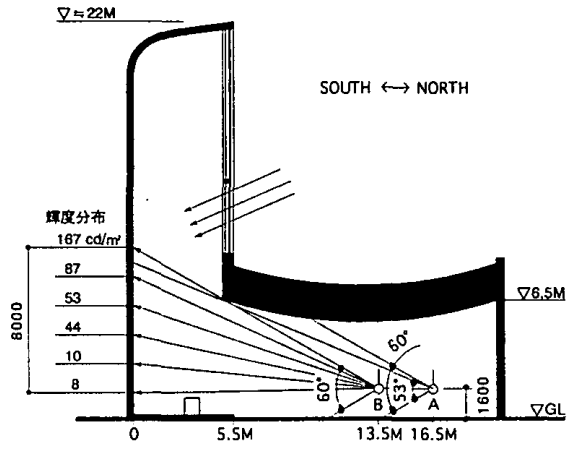

因 7 ロンシャン教会小聖堂 南北断面図と輝度分布
の小聖堂の光を正面中央に見やすい視点場となってい

る。この光から $16.5 \mathrm{M}$ 下がったところ（A点）から水平 に静視野60度で平面的に検討した場合、正面の光を幅 3 $\mathrm{M}$ とすると視角は10度であり、その周囲の卆間の全体も 60 度の視野内に収まる。断面的にはその祭壇部分から筒 の上部へと続く線的な光が視野上限60度の少し手前で、

天井に切られる。ここでは光が視野上限を越えてはいな いが、天井に切られることによってより上へと続いてい く効果がある。そしてその光に近付くにつれてその天井 の見切りは視野上限に収まらなくなり、光自体が視野上 限を越えてその上方へと光が延びてくように知覚でき る。光から約13.5Mのところ（B点）で、その光は視野 の上限を越える。

その光は粗い石灰吹き付けの壁面を下へと伝いながら 漸進的に変化する様がよく知覚できる。B点アイレヴェ

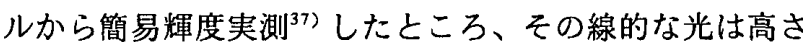
$8 \mathrm{M}$ に対し上端部で $167 \mathrm{~cd} / \mathrm{m}^{2}$ 、下端部で $8 \mathrm{~cd} / \mathrm{m}^{2}$ と 漸進的に輝度が変化していた（図 7）。

\section{（3）軸上目標光}

軸上目標光タイプは、空間形態の持つ軸の端部あるい は中央部といった軸上（位置）に点的にある（形態）光 が、目標や目印としてそこへと集中するようにその軸線 を方向づけ、空間に方向性をあたえるものである ${ }^{38)}$ 。

光之空間の知覚状態は、空間形堵によって限定方向つ けられた視線方向において、視野内の大部分を占める視 線に平行な面とその面の集中する先端の光を同時知賞す る、に整理できた。

ヴァリエーションは、光の位置の軸上はその軸の方向 に着目し、1）水平軸と2）鉛直軸に整理した。また光形 態の点的光はさらに、1）点状点的光、2）面状点的光、

3）線状点的光に整理した。

ここでは、水平軸端部に点状点的光をもつスカラ・レ ジアと鈆直軸端部に面状点的光をもつグッケンハイム美 術館を解説する。

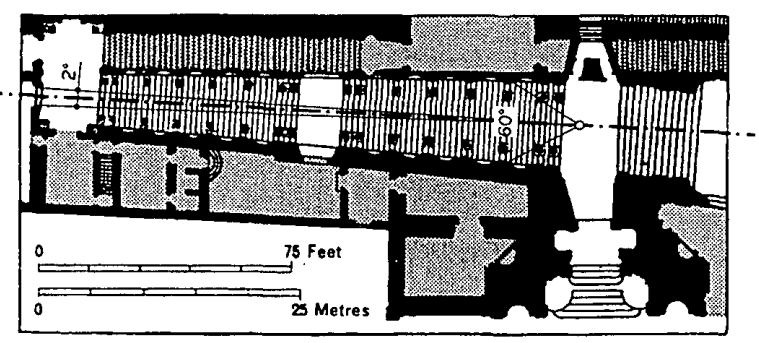

图 8 スカラ・レジア 平面図 
1) ス方ラ・レジア（図 8)

EX9: Scala Regia / St. Pietro, Roma, Italy /1663-69 / Berrini

空間に対する自然光の構成 : 長さ約 $60 \mathrm{M}$ 、高低差約 10 $\mathrm{M}$ 登る幅約 8〜 $5 \mathrm{M}$ と先細りの階段空間であり、空間 形態自身が強い方向性をもっている。その階段を登り きった形態軸上先端の踊場に幅約 $1.8 \mathrm{M}$ 高さ約 $3.3 \mathrm{M}$ の空 間全体に対し小さく点的なステンドグラスの光がある。 光と空間の知覚状態：2つの建物の間に增筑されたこ ともあって閉じられた空間において、その光は明るく際 立って輝いている。杢間形態によって主たる視線方向は 通路方向に限定されるが、その知賞状態は視野内の大部 分を占める視線に平行な面とその先端の際だった小さい 光が同時知賞できる。

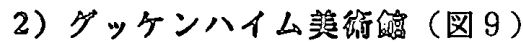

EX10: Solomon R. Guggenheim Museum /

New York, New York, USA $/ 1959 /$ F.L.Wright

自然光の構成 : 螺旋状に昇るスロープに囲まれた高さ 約 $29 \mathrm{M}$ 、直径約 $18 \mathrm{M} \sim 15 \mathrm{M}$ と上方にいくに従い先細りの 吹き抜け空間であり、空間形態自身が鈶植方向の軸性を 持っている。そしてその吹き抜け上部に直径約 $17.5 \mathrm{M} の$ 円形で面状の乳白ガラスのトップライトの光がある。

光の知覚状態：自由に動けるそのホールでは、上方か ら降り注がる光によって自然に上方へ上視線が導かれ る。ホール床から上方を見上げた場合、視線に平行な面 とその先端にある面状の点的光が同時知覚できる。

\section{6. 悹と的}

1）対象実例の観察を主たる方法として、まとまりと方 向性を与える自然光タイプを主要な原理に着目して、空 間に対する自然光の構成及びそれら光と空間の知覚状態 に求めた。その結果、まとまりについて、1.1 中心光、 1.2 包囲光、1.3 充満光、万向性について、2.1 軸線光、 2.2 軸上目標光の計 5 つの自然光タイプを得た。又それ それのタイプにおいて、それら特性生成における光の空 間的役割を得た（表 1 ）。

これらは主として既往理論の内部空間の光への応用に

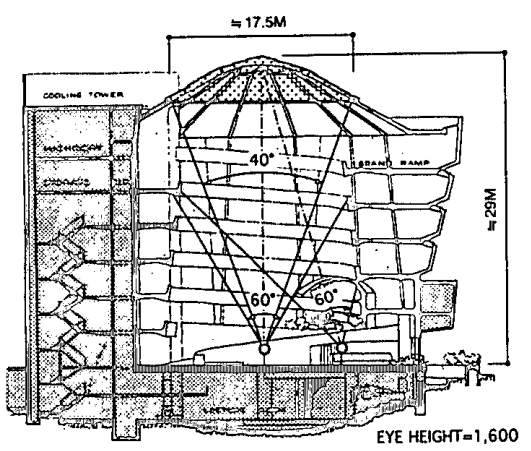

图 9 グッケン八イム美術館 断面図
よるものが多いが、1.3充満光については、物にはない 自然光に特徴的なものと考える。

通常昼光設計方式は頂光、頂側光、㑡光など、位置に よる分類のものがよくいわれているが、本研究で得たま とまりと方向性を与える自然光タイプは、架間特性を考 慮した自然光の採光方式として意㙅をもつと考える。

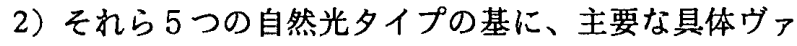
リエーション代表例を整理できた（表 1）。

このことは、空間の構造要素となり空間を豊かに生き つかしている建築空間が多数存在することを示すと共 に、その自然光タイプが具体的な設計への応用可能な一 般性のあること、そして本研究で設定した視点の有効性 を示していると考える。また整理したヴァリエーション 例は採光設計の基嘫的資料として役立つと考える。

\section{7. 唌䭪}

1）一つの架間単位内におけるまとまりと方向性を与え る自然光タイプを捉えたが、2つの空間を跨ぎ貫く光や 複数空間の交点に位置する光のように、複数空間をまと める光などもある。今後、複数空間における自然光と空 間特性との関係について検討の余地があると考える。 2）まとまりと方向性といった空間特性と主に空間に対 する自然光の構成との関係を捉えたが、光自身の質的特 徴それ自体が望間の大きな魅力となっていることも多 い。今後、光自身の質的操作とそれが与える効荲に着目 した研究もあわせて行ない、空間に対する自然光の構成 と光自身の実質的特徵の両侧面から自然光の空間演出を 考えることが、魅力的な自然光をもつ建築空間設計にむ けて有効と思われる。

写真揭載を快く許可してくださった関和明先生（関東学院 大学）、関連研究を通し協力を得た細矢仁、川辺直裁、清水 真紀子、作図協力を得た菊地宏諸氏に感謝の意を表します。

注

1）実際の物理的移動を伴うものと意識としてのみの運動衙動がある （文献 h ）p.6)

2）それらは、建築や都市空間における、物や空間の形の特性及びそ のつくりかたについて論したもの ${ }^{3)}$ 、それら空間の權成要素お 上びその特性について論じたあの4)にみられる，また絵画など における構図について論したもの ${ }^{5} 、$ 、゙シュタルト心理学の図と

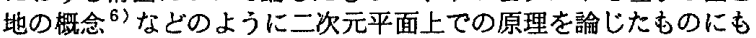
みられる。

3）主に文解a）b）c）を参考にした.

4）主に文献ｄ）e） f） g） h）を参考にした. 特に志水らのd） 「外部空間の權成要素とその構造特性に関する研究」は、e )

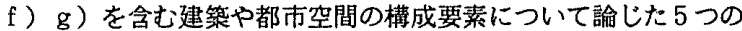
主要文献の比皎検討により、空間の構成要素の特性を整理しそれ ら構成要素の相互関係を教察している点から、多くを参照した。

5）主に文献 i ） j）を参考にした.

6) 主に文献 j) k) を参考にした.

7）母体とした資料は、本研究室における20数年にわたる光空間（光 を主要素とする空間) 研究て扱った数千例であり、光をテーマと した研究書および写真集、近代建築および各種歴史的な様式建筑 の研究書および写真集などから光空間として選定し、資料収集、 実地調查等を行なってきたものでるる 
8 ）対象とした実例については、平・断面図と空間に対する自然光の 構成およびその光と空間の知覚状態を読み取り易くすへく作成し たアクソノメトリック図、そして空間全体を示す写真（サービス 版）からなるテータシートを作成し実例分析の資料とした。

9) 約 60 例

10）既報「ウィーン郵便眝金局の空間構造と光」（文献m））では、 実例に対する第 3 者の記述及び研究者の実地観察上り捉えた空間 のイメージ構造を要素の物理的条件とその知覚状態によりよく説 明できた。

11）その際、2)であげた既往理論が本研究で扱う内部空間における 自然光という対象に対し適応可能な理譣かどうかをよく吟味した 上で、適応可能と考えたものについて参照した。

12）代表例においても、タイプの複合としてあるいはタイプの中間と して位㯰付けられるものが多いが、本稿では各自然光タイプの内 容説明に主眼をおき代表例を解説する。

13）志水らは、外部空間の構成要素の一つとしてあげた「場所」 ${ }^{14)} の$ 特質として「中心性亡有限の広がり」を指摘した上て、その秩序 つけられた内部として体験される「場所」のつくりかたとして、 中心を強く意識させる場合と境界により広がりを限定する場合の 2つを挙げている（文献 d ）、p.90）。また他文献にもこれに類 似した記述は多くみられる。

14）そこては用語として「空間」ではなく、「場所」としてその特質 が言及されているが、それらは本研究て対象とする内部空間の特 質として読み変えて適用てきると考えた。リンチや志水等は都市 写間や外部空間之いった大スケールの空間を対象にし、地として 広がる空間を領域や周域として定義し、その地の上に比較的まと まった特徵を具えた図として現れる要素を「場所」と定義してい る. そのため、その「場所」は既にまとまりをもった「内部空 間」として解釉して差し支えないと判断した. 志水らも、空間の スケールの階層性によっておこる構成要素の多義性の問題につい て指摘している(同上書、p.92)

15）空間の中央付近におかれた小さな要素が、その周囲の空間をまと め空間全体を引き締まったものにする原理は、広場空間の”核広 堨”（文献b）（下）、 p .60) や絵画における”アクセント”の 概念 (文献 j ) 、 p 51) にみられる。市た空間限定の初原的在り 方として、原空間のなかに何かの物体をおいた場合、その要素の 周囲にある種の圈を形成する原理が「中心的限定」と呼ばれてい る（文献c）、p.97）。これらの理論からも、中央近傍にある際 立った自然光が空間をまとめる要素になり得ると考えられる。

アルンハイムは絵画や建築空間における中心について「それは たいてい力の場の中心 力がそこから発生し、そこへと収漣する 焦点の意味である」としている（文献 i ）、p.13）

16) 中心の位固は、幾何学的中央と合致することが多いが、図形や空 間の視覚的な力動的な意味での中心であり、またイメージの中心 てあるため、必ずしも一致しているとは限らないことも言及され ている（文献 i ）p.11〜15、および文献））p.90)。ここでは、 中心になりやすい位置として、空間形熊中央近傍と整理した

17）線状点的光は、その線状のスケールが大きく空間に対して線的に なると後述する軸線光となり空間に方向性を与える光にもなる。

18）文献 i ) p.110.

19）エーロ・サーリネン、A + U、8404臨時増刊号、 p . S2

20) 文献 a) p . 72

21）二次元平面上での図としてのまとまりの原理において、連続する 線によって、互いに䦥じあっている図形はまとまりやすいとされ ている（文献 j ）p.29）。又絵画などにおいて、輪郭線を強くす るこ亡が内容を充実し、領域内の固さを增す効果があると言及さ

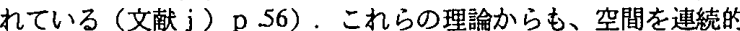
に包囲する光が空間の境界として視知覚的に強調されることに よって、空間にまとまりを与えると考えられる。

22) 求心形の形態はまとまりある形であることはよく言及されてい る。たとえば文献 a ) b ) c) など.

23） 1992年 7 月 26 日快晴 $11: 30$ 頃（外部水平面照度：䄪 $92.000 \mathrm{~lx}$ ）実

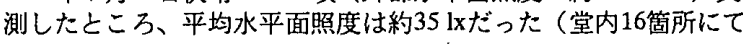
測定)

24）その光の輝きは「快晴には金色に輝き、月のもとに銀色に、莀 りの日にはグレーに、青い空にはうす青く輝く。」と指摘されて いる（二川幸夫（写真）、生田勉・三沢浩（文）：フランク・ロ イド・ライト 1、美術出版社、1972)

25）香山锿夫：フランク・ロイド・ライト1954-59、ベス・ショロー ム・シナゴーグ、A+U、8207、pp.15-20.

26）ゲシュタルト心理学において，全体としてまとまりがあり十分に 統一された、その図となる物は、地とは異なった特質（異質性） をむち、地に対する分離力が生じる一方、巣位を形成している物 の間には擬集力が濑くとされている。そしてその例の一つとし
て、白い紙の上にインクを落した時にインクじみの各部分が、そ の単位間の等啠性に上って疑集することが挙げられている(文献 j) p.22、下線研究者)

27）このタイプは包囲光によって二次的に生じることが多い

28）徳理屋（文献 1））は研究者の実地体験と第 3 者の実地アンケー 卜から、ウィーン郵便貯金局（文献m））は、研究者の実地体験 と第 3 者の実例に対する記述からイメージ構造を捉えた。

29）文献 1) p.58.

30) 文献m) p.72.

31) 文献m) p.72

32) 文献m) p.73

33） 1992年 7 月 7 日 $14: 00$ 頃、睛（外部水平面照度 : 約 43.0001x） ホール内21箇所にて測定

34）この軸線光は空間に方向性をあたえるとともに、中心軸としてそ の光に集中するように空間をまとめる効果もあわせもつ場合があ る.

35）渐進状線的光は、光による軸線の可視化とその明るい先を目標に そこへと方向付けられるという意味て、軸線光と後述の目標光と の複合としても位置付けられる。

36) 1992 年 7 月 27 日、14:00時頃、晴天（外部水平面照度 : 約 40.000 $1 \mathrm{x})$ ．水平面照度は、祭增手前 $7 \mathrm{M}$ で $251 \mathrm{x}_{\text {。 }}$ 祭壇上て $18 \mathrm{~lx}$ だっ た.

37) 同日同時刻.

38）このタイプは、中心光と同しく光が集中点となる原理てあるが、 空間形態のもつ軸性と光による集中性が組み合わさったものであ る。

39）志水らは、ランドマークなどに代表される、空間の特異点として 認識され空間を図式化して理解することに役立つサイン機能及び シンボル機能をもつ要素を〈しるし〉として整理した上て、〈く るし〉は「〈通路〉に目標・焦点をあたえ、軸性を強化する役割 をもつ」としている（文献ｄ） p .91、94）。またダゴベルト・フ ライも「目標とは進路が輻㚘する点、或は進路に方向性を与える もの」としている（文献h） p .6）。

\section{参考文触}

a) フランシス.D.K.チン、太田邦男訳 建築のかたちと空間をデザインする、彰国社、1987.

b) R.アルンハイム、乾正雄訳：建築形態のタイナミクス（上） （下）、鹿島出版会、1980.

c）岩本芳雄他：空間の限定、建筑文化、20巻226号、 pp.92-106、1965

d) 志水英樹、福井通 : 外部空間の構成要素とその構造特性に関する 研究、日本建築学会計画系論文報告集、第 372 号、 pp.86 99、1984.2.

e ） C.N.シュルツ、加藤邦男訳 : 実存・架間・建築、鹿島出版会、 1973.

f）ケヴィン・リンチ、丹下健三訳 : 都市のイメージ、岩波書店、 1968

g）樋口忠彦：景観の構造、技報堂、1975

h）タゴベルト・フライ、吉岡健二郎訳 : 比較芸術学、創文社、 1961.

i ）R.アルンハイム、関計夫訳 : 中心の力-美術における構図の 研究一、紀伊国屋畫店、1983.

j) 本明宽：改訂造形心理学入門、美術出版社、1962.

k）高橋研究室 : かたちのデータファイル、彰国社、1984.

1) 鈴木信宏、明田川洋: 徳利屋いろりの間の空間構造と光、 日本建築学会計画系論文埌告集、第421号、pp.51 61、 1991.3.

m）明田川洋、鈴木信宏 : ウィーン郵便眝金局出納ホールの空間構造 之光、日本建築学会計画系論文報告集、第444号、pp.67 76、 1993.2

n）桶師徳行、小泉隆、鈴木信宏 : 光による空間統合のプロトタイプ とヴァリエーション、日本建築学会学術講演梗概集、No. 5571、 1994.9。

o）小泉隆、藤井俊洋、鈴木信宏 : 入射光の性質からみた落ち着きを もたらす透過光障子面のイメージと連結感及びその作り出し手 法、日本建築学会計画系論文報告集 第457号、 pp.117-123、1994.3.

p) KOIZUMI Takashi, SUZUKI Nobuhiro: The Images of the Spaces Enclosed by the Light and Their Physical Elements, 12th IAPS Proceeding Vol. III , pp.9-18, The Aristotle Univ. of Thessaloniki, 1992.07

q）日本建築学会編：昼光照明の計画、設計計画パンフレット30、 彰国社、1985.

（1995年 5 月10日原稿受理，1995年11月22 日採用決定） 